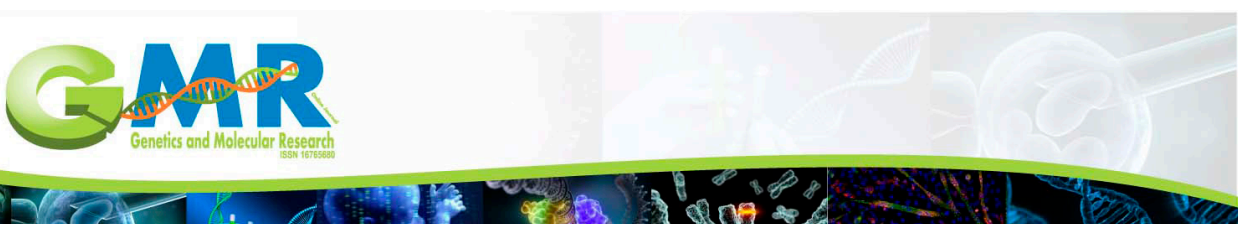

\title{
Analysis of POU1F1 gene Ddel polymorphism in Chinese goats
}

\author{
M.J. Li ${ }^{1,2}$, C.M. Zhang' ${ }^{2}$ X.Y. Lan' ${ }^{1}$ X.T. Fang ${ }^{3}$, C.Z. Lei ${ }^{1}$ and H. Chen ${ }^{1}$ \\ ${ }^{1}$ College of Animal Science and Technology, Northwest A\&F University, \\ Shaanxi Key Laboratory of Molecular Biology for Agriculture, Yangling, Shaanxi, China \\ ${ }^{2}$ Key Laboratory of Crops with High Quality and Efficient Cultivation and Security \\ Control, Yunnan Higher Education Institutions, Honghe University, Mengzi, Yunnan, \\ China \\ ${ }^{3}$ Institute of Cellular and Molecular Biology, Xuzhou Normal University, Xuzhou, \\ Jiangsu, China
}

Corresponding author: $\mathrm{H}$. Chen

E-mail: mijieli@126.com / chenhong1212@263.net

Genet. Mol. Res. 15 (1): gmr.15017747

Received September 29, 2015

Accepted December 3, 2015

Published March 11, 2016

DOI http://dx.doi.org/10.4238/gmr.15017747

ABSTRACT. As a member of the POU-domain family, the POU1F1 is a positive regulator for growth hormone, prolactin and thyroid-stimulating hormone $\beta$, by binding to target DNA promoters as a dimer in mammals. This study described the polymorphisms at the goat POU1F1-Ddel locus and analyzed the distribution of alleles in 15 indigenous Chinese goat breeds. The PCR-RFLP analysis showed a predominance of the $D_{1} D_{1}$ genotype and the $D_{1}$ allele, with average frequencies of 0.550 and 0.790 , respectively, irrespective of goat utility type. The $D_{1} D_{2}$ genotype was the second most frequent, with a mean frequency of 0.371 . The distributions of genotypic and allelic frequencies at this locus were found to be significantly different among populations based on a Chi square test $(P<0.001)$, suggesting that the breed factor significantly affected the molecular genetic character of the POU1F1 gene. The genetic diversity analysis revealed that Chinese indigenous populations had a wide spectrum of genetic diversity at the goat POU1F1-Ddel locus. However, an ANOVA analysis revealed no 
significant differences in gene homozygosity, gene heterozygosity, effective allele numbers, or polymorphism information content among meat, dairy, and cashmere utility types $(P>0.05)$. This suggests that the goat utility types had no significant effect on the spectrum of genetic diversity.

Key words: Goat; POU1F1 gene; Polymorphism; PCR-RFLP

\section{INTRODUCTION}

As a member of the POU-domain family, POU1F1 (also called PIT-1 or GHF-1) is a positive regulator for growth hormone $(\mathrm{GH})$, prolactin $(\mathrm{PRL})$, and thyroid-stimulating hormone $\beta$. It does this by binding to target DNA promoters as a dimer in mammals (Bodner et al., 1988; Lin et al., 1992; Tuggle and Trenkle, 1996). The inhibition of POU1F1 synthesis has been associated with a marked decrease of both $\mathrm{GH}$ and $\mathrm{PRL}$ expression and proliferation of somatotropic and lactotropic cell lines (Castrillo et al., 1991). POU1F1 mutations are associated with the Snell dwarf and Jackson dwarf mutations in mice, as well as dwarfism in human (Li et al., 1990; Pfäffle et al., 1992; Reynaud et al., 2004). Moreover, polymorphisms in the POU1F1 gene are associated with important quantitative traits in cattle (Renaville et al., 1997a,b; Zhao et al., 2004; Huang et al., 2008; Khatib et al., 2009) and in pig (Yu et al., 1995; Stanceková et al., 1999; Sun et al., 2002). Recently, polymorphisms in the sheep POU1F1 gene were reported by Bastos et al. (2006). All these efforts have been concentrated mainly on mice, humans, cattle, pigs, and sheep. The RFLP within the goat POU1F1 gene, with respect to the Ddel restriction enzyme (POU1F1-Ddel), was first identified by Lan et al. (2007). However, no comprehensive information on the status of the genetic diversity at this important gene locus is available in indigenous Chinese goat breeds.

The goat industry constitutes an important part in the so-called big domestic animals sector in China. The estimated extent is more than 157,361,000 animals, belonging to more than twenty native breeds (e.g., dairy, meat, and wool breeds) that are mainly reared in the northern China. Therefore, the present study was planned with the objective to reveal the distribution pattern of known variants at the goat POU1F1-Ddel locus using a PCR-RFLP approach. We did this in various Chinese goat breeds from different regions, with the aim of providing information on the present goat genetic resources.

\section{MATERIAL AND METHODS}

\section{Genomic DNA isolation}

Genomic DNA samples were obtained from 709 goats belonging to six genetic types: Nanjiang cashmere goat $(\mathrm{N}=247)$, Xinjiang goat $(\mathrm{N}=175)$, Shaanbei White cashmere goat $(\mathrm{N}=$ $150)$, Boer goat $(N=84)$, Haimen goat $(N=33)$, and Xuhuai goat $(N=20)$ reared in the Chinese provinces of Xinjiang, Shaanxi, and Jiangsu, respectively. DNA samples were extracted from leucocytes and ear tissue according to Sambrook et al. (1989).

\section{PCR conditions}

The primer pairs reported by Lan et al. (2007) (F: 5'-CCATCATCTCCCTTCTT-3' and R: 5'-AATGTACAATGTGCCTTCTGAG-3') were synthesized to amplify the goat POU1F1 gene in- 
cluding exon 6 and its flanking region. The PCR was performed in a $25-\mu \mathrm{L}$ reaction mixture containing $50 \mathrm{ng}$ genomic DNA, $0.5 \mu \mathrm{M}$ each primer, $1 \mathrm{X}$ buffer (including $1.5 \mathrm{mM} \mathrm{MgCl}$ ), $200 \mu \mathrm{M}$ dNTPs, and $0.625 \mathrm{U}$ Taq DNA polymerase (Dingguo, Beijing, China). The cycling protocol was $4 \mathrm{~min}$ at $95^{\circ} \mathrm{C}, 35$ cycles of denaturing at $94^{\circ} \mathrm{C}$ for $45 \mathrm{~s}$, annealing at $54.5^{\circ} \mathrm{C}$ for $45 \mathrm{~s}$, extending at $72^{\circ} \mathrm{C}$ for $1 \mathrm{~min}$, with a final extension at $72^{\circ} \mathrm{C}$ for $10 \mathrm{~min}$.

\section{Genotyping of POU1F1-Ddel allele using PCR-RFLP}

Aliquots of $20 \mu \mathrm{L}$ PCR products of POU1F1 gene were digested with $10 \mathrm{U}$ Ddel at $37^{\circ} \mathrm{C}$ for $5 \mathrm{~h}$. The digested products were detected using 12.0\% PAGE electrophoresis and stained with $0.1 \%$ silver nitrate.

\section{Statistical analysis}

Genotypic and allelic frequencies were calculated directly. Differences in these frequencies at the POU1F1-Ddel locus among Chinese populations were analyzed using Chi square tests, which were performed using SPSS (v. 13.0). The population genetic indices, such as gene homozygosity $\left(H_{O}\right)$, gene heterozygosity $\left(H_{E}\right)$, effective allele numbers $\left(N_{E}\right)$, and the polymorphism information content (PIC), were calculated using the methods of Nei and Roychoudhury (1974). For these analyses, we included not only the six breeds analyzed in the present study, but also the nine breeds reported by Lan et al. (2007).

\section{RESULTS AND DISCUSSION}

When screening the POU1F1-Ddel for polymorphisms in 709 indigenous Chinese goat individuals, two alleles $\left(D_{1}, D_{2}\right)$ and three genotypes $\left(D_{1} D_{1}, D_{1} D_{2}\right.$, and $\left.D_{2} D_{2}\right)$ were identified. The genotype and allele frequencies of POU1F1-Ddel variants in each of the 15 Chinese goat breeds analyzed are listed in Table 1. The DNA restriction fragments corresponding to the $D_{1} D_{1}, D_{1} D_{2}$, and $D_{2} D_{2}$ genotypes were: 200, 118, 102, 20, and 11 bp; 200, 118, 113, 102, 20, and 11 bp; 200, 118,113 , and $20 \mathrm{bp}$, respectively. Because the two small bands (20 and $11 \mathrm{bp}$ ) were not visible on the 12.0\% PAGE electrophoresis, only three bands (200, 118, and $102 \mathrm{bp}$ ), four bands (200, $118,113$, and $102 \mathrm{bp})$, and three bands $(200,118$, and $113 \mathrm{bp})$ were visible for genotypes $D_{1} D_{1}$, $D_{1} D_{2}$, and $D_{2} D_{2}$, respectively (Figure 1 ).

Most of the studied goat breeds demonstrated a high proportion of the $D_{1} D_{1}$ genotype that ranged from 0.200 (Laoshan) to 1.00, with an average frequency of $0.550 \pm 0.177$ (Table 1). In the Guizhou Black goat population, $100 \%$ of the animals were homozygous for the $D_{1} D_{1}$ genotype. The $D_{1} D_{2}$ heterozygotic genotype was the second most frequent with a mean frequency of $0.371 \pm 0.203$. Interestingly, only four of the 15 goat breeds examined exhibited the homozygous $D_{2} D_{2}$ genotype. Similar distribution trends were observed for the $D_{1}$ and $D_{2}$ alleles in all the Chinese goat breeds irrespective of their functional type. The $D_{1}$ allele was found to be the predominant allele with an average gene frequency as high as $0.790 \pm 0.117$. The frequency distribution of the $D_{1}$ allele was significantly higher than the $D_{2}$ frequency distribution in all goat breeds and ranged from 0.581 (Nanjiang) to 1.00, with the Guizhou Black goat breed showing the highest frequency (Table 1). On the other hand, the $D_{2}$ allele was found to be distributed at a relatively low frequency (average: $0.210 \pm 0.116$ ). However, none of the Guizhou Black individuals were found to possess the $D_{2}$ allele. 
Table 1. Genotypic and allelic frequencies at the POU1F1-Ddel locus in 15 indigenous Chinese goat breeds.

\begin{tabular}{|c|c|c|c|c|c|c|}
\hline \multirow[t]{2}{*}{ Breeds } & \multirow[t]{2}{*}{$\mathrm{N}$} & \multicolumn{3}{|c|}{ Genotype frequencies } & \multicolumn{2}{|c|}{ Allele frequencies } \\
\hline & & $P_{D 1 D 1}$ & $P_{D 1 D 2}$ & $\mathrm{P}_{\mathrm{D} 2 \mathrm{D} 2}$ & $\mathrm{D}_{1}$ & $\mathrm{D}_{2}$ \\
\hline Nanjiang & 247 & 0.324 & 0.514 & 0.162 & 0.581 & 0.419 \\
\hline Xinjiang & 175 & 0.663 & 0.263 & 0.074 & 0.794 & 0.206 \\
\hline Shaanbei & 150 & 0.460 & 0.400 & 0.140 & 0.660 & 0.340 \\
\hline Boer & 84 & 0.774 & 0.226 & 0.000 & 0.887 & 0.113 \\
\hline Haimen & 33 & 0.576 & 0.333 & 0.091 & 0.742 & 0.258 \\
\hline Xuhuai & 20 & 0.700 & 0.300 & 0.000 & 0.850 & 0.150 \\
\hline InnerMongolia* & 452 & 0.750 & 0.250 & 0.000 & 0.875 & 0.125 \\
\hline XinongSannen* & 74 & 0.770 & 0.230 & 0.000 & 0.885 & 0.115 \\
\hline Laoshan* & 80 & 0.200 & 0.800 & 0.000 & 0.600 & 0.400 \\
\hline Guanzhong* & 62 & 0.694 & 0.306 & 0.000 & 0.847 & 0.153 \\
\hline GuizhouBlack $^{*}$ & 21 & 1.000 & 0.000 & 0.000 & 1.000 & 0.000 \\
\hline Matou* & 22 & 0.455 & 0.545 & 0.000 & 0.728 & 0.272 \\
\hline Banjiao* & 25 & 0.840 & 0.160 & 0.000 & 0.920 & 0.080 \\
\hline GuizhouWhite $^{*}$ & 31 & 0.355 & 0.645 & 0.000 & 0.706 & 0.294 \\
\hline Leizhou* & 34 & 0.412 & 0.588 & 0.000 & 0.777 & 0.223 \\
\hline Mean & 1510 & $0.550 \pm 0.177$ & $0.371 \pm 0.203$ & $0.031 \pm 0.055$ & $0.790 \pm 0.117$ & $0.210 \pm 0.116$ \\
\hline
\end{tabular}

The genotypic and allelic frequencies of breeds marked with asterisk are cited from Lan et al. (2007).

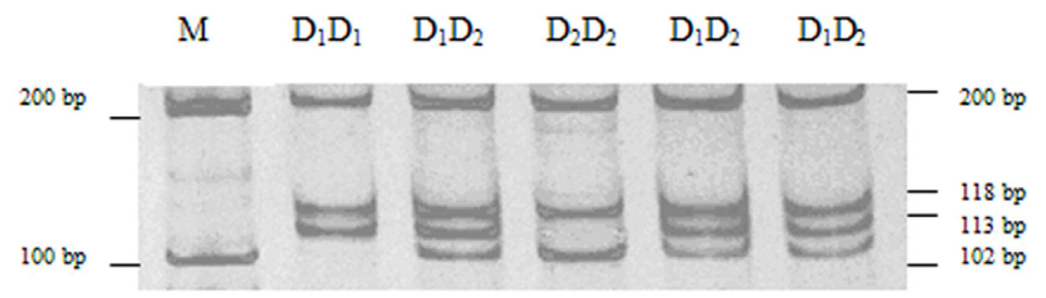

Figure 1. Ddel-digested POU1F1 PCR products on 12\% PAGE.

The genotypic frequencies for the various polymorphisms at the POU1F1-Ddel locus were found to be significantly different among the 15 populations, based on the chi-square test $\left(\chi^{2}=\right.$ 345.410 , d.f. $=28, P<0.001$ ). Significant differences in allelic frequencies among the Chinese goat populations were also revealed $\left(\chi^{2}=258.213\right.$, d.f. $\left.=14, \mathrm{P}<0.001\right)$. Thus, there were significant differences in both genotypic and allelic frequencies at the goat POU1F1-Ddel locus in indigenous Chinese goats. The breed factor significantly affected the distribution of the genotypic and allelic frequencies at the goat POU1F1-Ddel locus.

The $H_{\mathrm{O}}, H_{\mathrm{E}}, N_{\mathrm{E}}$, and PIC values for the studied populations are shown in Table 2. Comparisons of genetic diversity in the studied goat breeds demonstrated that the Nanjiang goat had the lowest $H_{\mathrm{O}}$ and the highest PIC. This result indicates that the Nanjiang population is not in a good homozygous status, which is consistent with its breeding background. The Nanjiang goat comes from the Liaoning cashmere and Xinjiang native goats. The Nanjiang goat breed thus originated from two distinctly different breeds and the resulting genetic variability in this breed provided the Xinjiang province with a much needed genetic improvement. Meanwhile, the Boer goat, a meat producing breed famous across the world, had a relatively higher homozygosity and lower a PIC. This breed was imported to improve meat production and growth in the indigenous goat breeds in the Jiangsu Province. However, the ANOVA analysis revealed that there were no significant differences in the four genetic indices in meat utility, dairy utility, or cashmere utility $(P>0.05)$, respectively (data not shown). This implies that the goat utility types had no significant effects on the spectrum of genetic diversity at the POU1F1-Ddel locus in Chinese goats. 
Table 2. Genetic diversity at the POU1F1-Ddel locus in 15 indigenous Chinese goat breeds.

\begin{tabular}{l|l|c|c|c|c}
\hline Breeds & Types & $H_{\mathrm{O}}$ & $H_{E}$ & $N_{E}$ & PIC \\
\hline Nanjiang & Cashmere & 0.513 & 0.487 & 1.949 & 0.368 \\
\hline Xinjiang & Meat & 0.673 & 0.327 & 1.485 & 0.273 \\
\hline Shaanbei & Cashmere & 0.551 & 0.449 & 1.814 & 0.348 \\
\hline Boer & Meat & 0.799 & 0.201 & 1.251 & 0.181 \\
\hline Haimen & Meat & 0.618 & 0.383 & 1.619 & 0.309 \\
\hline Xuhuai & Meat & 0.745 & 0.255 & 1.342 & 0.223 \\
\hline InnerMongolia* & Cashmere & 0.781 & 0.219 & 1.280 & 0.195 \\
\hline XinongSannen* & Dairy & 0.797 & 0.203 & 1.255 & 0.183 \\
\hline Laoshan* $^{*}$ & Dairy & 0.520 & 0.480 & 1.923 & 0.365 \\
\hline Guanzhong* & Dairy & 0.741 & 0.260 & 1.350 & 0.226 \\
\hline GuizhouBlack $^{*}$ & Meat & 1.000 & 0.000 & 1.000 & 0.000 \\
\hline Matou* $^{*}$ & Meat & 0.603 & 0.397 & 1.658 & 0.318 \\
\hline Banjiao $^{*}$ & Meat & 0.853 & 0.147 & 1.173 & 0.136 \\
\hline GuizhouWhite $^{*}$ & Meat & 0.563 & 0.44 & 1.776 & 0.342 \\
\hline
\end{tabular}

The genetic diversity of breeds marked with an asterisk are cited from Lan et al. (2007).

\section{ACKNOWLEDGMENTS}

Research supported by the National Natural Science Foundation of China (\#30972080 and \#30901023), the Program of National Beef Cattle Industrial Technology System (\#CARS-38), and the Agricultural Science and Technology Innovation Projects of Shaanxi Province (\#2012NKC01-13).

\section{REFERENCES}

Bastos E, Santos I, Parmentier I, Castrillo JL, et al. (2006). Ovis aries POU1F1 gene: cloning, characterization and polymorphism analysis. Genetica 126: 303-314. http://dx.doi.org/10.1007/s10709-005-0034-6

Bodner M, Castrillo JL, Theill LE, Deerinck T, et al. (1988). The pituitary-specific transcription factor GHF-1 is a homeoboxcontaining protein. Cell 55: 505-518. http://dx.doi.org/10.1016/0092-8674(88)90037-2

Castrillo JL, Theill LE and Karin M (1991). Function of the homeodomain protein GHF1 in pituitary cell proliferation. Science 253: 197-199. http://dx.doi.org/10.1126/science.1677216

Huang W, Maltecca C and Khatib H (2008). A proline-to-histidine mutation in POU1F1 is associated with production traits in dairy cattle. Anim. Genet. 39: 554-557. http://dx.doi.org/10.1111/j.1365-2052.2008.01749.x

Khatib H, Huang W, Wang X, Tran AH, et al. (2009). Single gene and gene interaction effects on fertilization and embryonic survival rates in cattle. J. Dairy Sci. 92: 2238-2247. http://dx.doi.org/10.3168/jds.2008-1767

Lan XY, Pan CY, Chen H, Lei CZ, et al. (2007). Ddel polymorphism in coding region of goat POU1F1 gene and its association with production traits. Asian-Aust. J. Anim. Sci. 20: 1342-1348.

Li S, Crenshaw EB, 3rd, Rawson EJ, Simmons DM, et al. (1990). Dwarf locus mutants lacking three pituitary cell types result from mutations in the POU-domain gene pit-1. Nature 347: 528-533. http://dx.doi.org/10.1038/347528a0

Lin C, Lin SC, Chang CP and Rosenfeld MG (1992). Pit-1-dependent expression of the receptor for growth hormone releasing factor mediates pituitary cell growth. Nature 360: 765-768. http://dx.doi.org/10.1038/360765a0

Nei M and Roychoudhury AK (1974). Sampling variances of heterozygosity and genetic distance. Genetics 76: $379-390$.

Pfäffle RW, DiMattia GE, Parks JS, Brown MR, et al. (1992). Mutation of the POU-specific domain of Pit-1 and hypopituitarism without pituitary hypoplasia. Science 257: 1118-1121. http://dx.doi.org/10.1126/science.257.5073.1118

Renaville R, Gengler N, Vrech E, Prandi A, et al. (1997a). Pit-1 gene polymorphism, milk yield, and conformation traits for Italian Holstein-Friesian bulls. J. Dairy Sci. 80: 3431-3438. http://dx.doi.org/10.3168/jds.S0022-0302(97)76319-7

Renaville R, Gengler N, Parmentier I, Mortiaux F, et al. (1997b). Pit-1 gene Hinfl RFLP and growth traits in double-muscled Belgian Blue cattle. J. Anim. Sci. 75 (Suppl. 1): 146. 
Reynaud R, Saveanu A, Barlier A, Enjalbert A, et al. (2004). Pituitary hormone deficiencies due to transcription factor gene alterations. Growth Horm. IGF Res. 14: 442-448. http://dx.doi.org/10.1016/j.ghir.2004.07.001

Sambrook J, Fritsch EF and Maniatis T (1989). Molecular cloning: a laboratory manual. 2nd edn. Cold Spring Harbour Lab. Press, New York.

Stanceková K, Vasícek D, Peskovicová D, Bulla J, et al. (1999). Effect of genetic variability of the porcine pituitary-specific transcription factor (PIT-1) on carcas traits in pigs. Anim. Genet. 30: 313-315. http://dx.doi.org/10.1046/j.13652052.1999.00484.x

Sun HS, Anderson LL, Yu TP, Kim KS, et al. (2002). Neonatal Meishan pigs show POU1F1 genotype effects on plasma GH and PRL concentration. Anim. Reprod. Sci. 69: 223-237. http://dx.doi.org/10.1016/S0378-4320(01)00177-4

Tuggle CK and Trenkle A (1996). Control of growth hormone synthesis. Domest. Anim. Endocrinol. 13: 1-33. http://dx.doi. org/10.1016/0739-7240(95)00059-3

Yu TP, Tuggle CK, Schmitz CB and Rothschild MF (1995). Association of PIT1 polymorphisms with growth and carcass traits in pigs. J. Anim. Sci. 73: 1282-1288.

Zhao Q, Davis ME and Hines HC (2004). Associations of polymorphisms in the Pit-1 gene with growth and carcass traits in Angus beef cattle. J. Anim. Sci. 82: 2229-2233. 